\title{
ANALISIS PENILAIAN KINERJA PORTOFOLIO SAHAM SYARIAH DENGAN METODE SHARPE INDEX
}

\author{
Anastasya Br Ginting1), Ahmad Ihsan Fiqih Siregar ${ }^{2)}$ \\ Universitas Islam Negeri Sumatera Utara \\ Fakultas Ekonomi Dan Bisnis Islam, Jurusan Manajemen \\ Jl. Willian Iskandar Pasar V, Medan Estate, Sumatera Utara \\ 1)anastasyabrginting465@gmail.com, 2Fiqihsiregar20@gmail.com
}

\begin{abstract}
Abstrak. Penelitian ini bertujuan untuk mengetahui penilaian kinerja portofolio saham syariah dengan metode Sharpe Index. Data penelitian ini menggunakan data sekunder yang diperoleh dari studi pustaka, literatur, jurnal-jurnal dan data yang telah dipublikasikan dan bersumber dari historical data yaitu harga saham setiap perusahaan. Cara pengumpulan data penelitian ini adalah studi pustaka dan dokumentasi. Objek penelitian ini adalah perusahaan Indah Kiat Pulp \& Paper Tbk (INKP) yang bergerak dalam bidang pembuatan kertas, pulpen dan kertas kemasan, perusahaan Vale Indonesia Tbk (INCO) yang bergerak dalam bidang pertambangan serta perusahaan Mitra Keluarga Karyasehat Tbk (MIKA) yang bergerak dalam bidang pelayanan kesehatan masyarakat/rumah sakit yang telah terdaftar di Jakarta Islamic Index (JII). Populasi penelitian ini terdiri dari 30 perusahaan yang terdaftar di Jakarta Islamic Index periode 2020 dan kemudian ditarik sampel menggunakan metode purpose sampling, yang menghasilkan 3 perusahaan yang dijadikan sampel. Hasil dari Sharpe Index menunjukkan bahwa Portofolio dari ketiga saham yang telah diteliti memiliki peringkat baik yang dapat dijadikan sebagai portofolio optimal seorang investor dalam berinvestasi.
\end{abstract}

Kata kunci : Penilaian Kinerja Portofolio, Saham Syariah, Sharpe Index

\begin{abstract}
This study aims to determine the performance appraisal of Islamic stocks using the Sharpe Index method. This research data uses secondary data obtained from literature studies, literature, journals and data obtained from historical data, namely the stock price of each company. The method of collecting data for this research is literature study and documentation. The object of this research is the company Indah Kiat Pulp \& Paper Tbk (INKP) which is engaged in the manufacture of paper, pens and packaging paper, the company Vale Indonesia Tbk (INCO) which is engaged in mining and the company Mitra Keluarga Karyasehat Tbk (MIKA) which is engaged in public health services/hospitals that have been recorded in the Jakarta Islamic Index (III). The population of this study consisted of 30 companies listed on the Jakarta Islamic Index for the 2020 period and then the sample was drawn using the purpose sampling method, which resulted in 3 companies being sampled. The results of the Sharpe Index show that the portfolio of the three stocks that have been achieved has a good rating which can be used as an optimal portfolio for an investor to invest.
\end{abstract}

Keywords: Portfolio Performance Assessment, Sharia Shares, Sharpe Index 


\section{PENDAHULUAN}

Investasi saat ini menjadi pilihan utama bagi masyarakat yang ingin meningkatkan nilai kekayaan yang dimiliki. Pertumbuhan investasi di Indonesia berkembang sangat pesat baik investasi jangka pendek dan investasi jangka panjang. Berdasarkan sumber dari Badan Koordinasi Penanaman Modal (BKPM), merilis bahwa dapat capaian realisasi investasi pada Triwulan I (periode Januari-Maret) untuk tahun 2021 sebesar Rp. 219,7 Triliun atau meningkat 4,3\% jika dibandingkan dengan Triwulan I 2020, sedangkan jika dibandingkan dengan triwulan sebelumnya meningkat sebesar 2,4\%. Bursa Efek Indonesia (BEI) yang berperan sebagai fasilitator dalam penjualan dan pembelian efek perusahaan baik dalam bentuk saham, obligasi, reksadana, dan surat berharga lainnya. Salah satu alternatif investasi yaitu saham. Perkembangan saham syariah di Indonesia juga menunjukkan statistik yang cukup baik. Sejak diluncurkan pada tahun 2011, Indeks Saham Syariah Indonesia (ISSI) tumbuh signifikan. Menurut data OJK per September 2016, nilai kapitalisasi saham syariah di Indonesia mencapai tiga ribu triliun rupiah atau 61 persen dari seluruh nilai kapitalisasi saham di Bursa Efek Indonesia (BEI)..

Investasi saham syariah tidak berbeda dengan investasi saham konvensional. Setiap investor memiliki pengharapan keuntungan yang sama dan meminimalisir tingkat risikonya pada masa yang akan datang. Perbedaan pengharapan investor adalah selain memperhatikan tingkat keuntungan dan risiko dalam berivestasinya, juga memperhatikan prinsip etika dan agama (Albaity, 2008). ${ }^{1}$

Dalam efek syariah Islam, investasi menggunakan prinsip dasar syariah Islam yang melarang aktivitas yang didalamnya terdapat unsur riba, perjudian, ketidakpastian dan melarang kegiatan seperti produksi barang dan jasa yang dilarang dalam syariah Islam misalnya pornografi, alkohol, usaha kasino dan lainya. Salah satu saham syariah adalah saham yang tercatat di Jakarta Islamic Index. Jakarta Islamic Index atau biasa disebut JII merupakan indeks saham di Bursa Efek Indonesia yang didasarkan atas prinsip syariah (Nafik, 2009:260). Jumlah saham yang berada di JII dipilih 30 saham yang terbaik setiap semesternya.

${ }^{1}$ Albaity, M., Ahmad, R., 2008, Performance Of Syariah And Composite Indices: Evidence From Bursa Malaysia, Asian Academy of Management Journal of Accounting and Finance.4(1), 23-43 
Para calon investor saat ini tidak sedikit yang memilih saham sebagai jenis investasi yang dimiliki dengan alasan bahwa dengan berinvestasi pada saham, maka return yang diterima akan maksimal jika dibanding dengan jenis investasi lain. Namun sebenarnya besarnya resiko dan tingkat perolehan (return) investasi memiliki hubungan yang positif atau searah, atau yang lebih dikenal high risk - high return, yang artinya semakin tinggi tingkat resiko yang dihadapi maka semakin tinggi pula return yang diharapkan. Investor dihadapkan pada bentuk investasi yang beresiko, maka investor perlu membentuk portofolio dengan melakukan diversifikasi investasi pada lebih dari satu saham (Suad Husnan, 1998:47). Namun, permasalahan diversifikasi portofolio adalah penentuan atau pemilihan sejumlah aset-aset spesifik tertentu dan penentuan proporsi dana yang akan diinvestasikan untuk masing-masing aset tersebut dalam portofolio yang optimal dan efisien.

Dalam usaha untuk mencari saham yang tepat dan dijadikan investasi, maka para investor sebaiknya melihat portofolio dari saham, karena masalah investor adalah bagaimana memilih saham dengan portofolio yang baik, sehingga investor diharapkan dapat memilih secara bijak dalam membeli saham. Dengan analisis portofolio menggunakan metode sharpe index, diharapkan para investor dan calon investor dapat melihat return dan risiko yang ada.

Rumusan masalah pada penelitian kami ini yaitu bagaimana menganalisis penilaian kinerja portofolio saham syariah dengan metode sharpe index ?. Adapun tujuan pada penelitian kami ini yaitu untuk menganalisis penilaian kinerja portofolio saham syariah dengan metode sharpe index yaitu pada perusahaan

\section{LITERATUR REVIEW}

Portofolio adalah sekumpulan proyek atau kombinasi investasi yang dimiliki oleh perusahaan untuk mengurangi risiko (Kamaludin, 2011:401). Jadi, portofolio adalah kumpulan berapa aset yang diinvestasi yang dilakukan oleh para investor dengan tujuan untuk meminimalisir risiko, dengan harapan akan menjadi sebuah portofolio yang optimal. Saham syariah adalah efek berbentuk saham yang tidak bertentangan dengan prinsip syariah di pasar modal.

Penilaian kinerja portofolio merupakan tahapan yang dilakukan oleh para investor untuk mengetahui apakah portofolio yang dibentuk telah menghasilkan suatu kinerja yang 
baik. Adapun metode penilaian kinerja portofolio yang kami gunakan dalam penelitian ini yaitu metode sharpe index.

Sharpe (1966) ialah pengembang dari model indeks sharpe yang mengukur dan memprediksi kinerja reksadana atau portofolio berdasarkan teori pasar modal dan perilaku harga pasar saham. Dia menunjukkan bahwa kinerja keuangan saham secara teoretis dapat diukur dengan cara membagi rata-rata return per unit dengan total risiko per unit, dengan persamaan sebagai berikut.

$$
S R=\frac{(R i . t-R f . t)}{\sigma(R i . t)}
$$

Dimana

SR : nilai rasio Sharpe,

Ri.t : rata-rata return saham,

Rf.t : rata-rata keuntungan investasi bebas risiko,

$\sigma(R i . t)$ : standar deviasi rata-rata return saham.

Indeks Sharpe akan digunakan untuk memberikan peringkat dari beberapa portofolio saham. Semakin tinggi indeks Sharpe suatu portofolio dibandingkan dengan portofolio lain, semakin baik kinerja portofolio tersebut (Tandelilin, 2010).

Penelitian terdahulu yang dilakukan oleh Asti Priyanti, dkk. pada Mei 2021 lalu menyatakan bahwa didalam penelitiannya yang digunakan dalam mengukur kinerja portofolio dengan metode sharpe metode ini mengukur tingkat risiko total dari portofolio. Penelitian yang dilakukan yaitu pada tujuh perusahaan yang terdaftar di indeks LQ 45 pada tahun 2015-2019 yang dijadikan sample dan hanya lima saham yang masuk ke dalam portofolio. Hasil perhitungan evaluasi performa portofolio secara keseluruhan berdasarkan metode Sharpe memiliki nilai positif yakni sebesar 0,2088 dimana nilai tersebut masih lebih besar dibanding tingkat pengembalian pasar yang hanya sebesar 0,0447. Hal ini menandakan portofolio yang dibentuk memiliki kinerja yang baik walaupun dengan tingkat risiko yang cukup besar yakni sebesar 0,3106. ${ }^{2}$

2 Asti Priyanti, Immas Nurhayati, Renea Shinta Aminda, dan Rasiman.(2021). ANALISIS EVALUASI KINERJA PORTOFOLIO SAHAM DENGAN METODE SHARPE. Jurnal Manager Vol.4 No.2.hal. 174-181. 
Institut Agama Islam Sunan Kalijogo Malang P-ISSN 2715-7725 E-ISSN 2721-9496 Volume 3 Nomor 2 Desember 2021

Alwahidin (2020) dalam hasil penelitiannya terdahulu menjelaskan mengenai kinerja portofolio pada saham-saham syariah dan konvensional yaitu kinerja portofolio saham syariah, baik itu dari indeks syariah maupun dari portofolio saham syariah yang dibentuk secara acak kalah dibandingkan dengan kinerja indeks dan portofolio saham konvensional ketika menggunakan empat ukuran kinerja risk adjusted model melalui model Sharpe, Tryenor,M2, dan Jensen's alpha, namun apabila diukur berdasarkan kelompok tahun, kinerja portofolio saham syariah menunjukan kinerja yang sangat baik pada awal pembentukan ISSI dan setahun setelahnya, yaitu pada tahun 2011 dan 2012, kinerja ISSI mengungguli kinerja tujuh indeks konvensional pembandingnya, saham-saham syariah juga menunjukkan kinerja yang unggul ketika masa resesi atau krisis. ${ }^{3}$

Penelitian penilaian kinerja portofolio pada saham syariah dengan menggunakan metode sharpe juga dilakukan oleh Muthia Damayanti, Titing Suharti dan Diah Yudhawati (Februari, 2021) bahwa 2 dari 3 saham perusahaan yang diteliti masuk kedalam kriteria pembentuk portofolio dikarenakan nilai $E(R i)>E(R m)$ yaitu PT.Pembangunan Perumahan (Persero) Tbk dan PT.United Tractors Tbk dan yang tidak termasuk kedalam kriteria pembentuk portofolio dikarenakan nilai $\mathrm{E}(\mathrm{Ri})<\mathrm{E}(\mathrm{Rm}) .4$

Elisa Vine Nurdhianal dan Dr.Norita,S.E.,M.Si.,Ak (2017) pada penelitiannya menyatakan bahwa penilaian kinerja portofolio menggunakan metode Sharpe ratio mendapatkan hasil kinerja terbaik pada portofolio F dengan indeks sharpe sebesar 21,191\% yang dimana penelitiannya dilakukan pada Indeks Saham Syariah Indonesia (ISSI) tahun 2011 sampai dengan 2015. 5

Penelitian terdahulu Atik Budi Paryanti dan Sri Lestari (2016) dalam penelitiannya menjelaskan bahwa penelitian yang dilakukan untuk penilaian kinerja portofolio yaitu terdapat 6 kombinasi portofolio dari 8 saham perusahaan yang terdiri dari sektor keuangan,

\footnotetext{
${ }^{3}$ Alwahidin.(2020). Kinerja Portofolio Saham Syariah dan Faktor yang Memengaruhi Kinerja Saham Syariah di Indonesia. Jurnal Studi Ekonomi Dan Bisnis Islam Volume 5, No.1.

${ }^{4}$ Muthia Damayanti, Titing Suharti dan Diah Yudhawati. (2021). Penilaian Kinerja Portofolio Saham Syariah Dengan Metode Sharpe Index. Jurnal Manager Vol. 4, No. 1.

5 Elisa Vine Nurdhiana dan Dr.Norita,S.E.,M.Si.,Ak. (2017). Analisis Pembentukan Portofolio Optimal Menggunakan Capital Asset Pricing Model Serta Penilaian Kinerja Portofolio Berdasarkan Metode Shrape Ratio, Treynor Ratio, Dan Jensen. Jurnal e-Proceeding of Management : Vol.4, No.1.
} 
pertambangan, property dan real estate, industri barang konsumsi, dan transportasi, utilitas, dan infastruktur. Berdasarkan hasil analisis metode Sharpe measure yang dilakukan dapat dijelaskan saham individual yang termasuk dalam kandidat portofolio optimal periode januari 2008 hingga desember 2010 diperoleh 3 kombinasi portofolio terbaik yang pertama pada kombinasi 4 (BMRI, ANTM, ASRI, KLBF, dan PGAS) sebesar 0,545, kombinasi 1 (BBNI, ADRO, ASRI, KLBF, dan PGAS) sebesar 0,523, dan kombinasi 2 (BBNI, ANTM, ASRI, KLBF, dan PGAS) sebesar 0,270 yang dimana saham-sahamnya berada di sektor keuangan, pertambangan, property dan real estate, industri barang konsumsi, dan transportasi, utilitas, dan infastruktur. ${ }^{6}$

Penelitian terdahulu Mutmainah (2017) bahwa return yang tinggi belum tentu memiliki kinerja yang baik. Saham pasar mempunyai return yang lebih tinggi dari pada return portofolio. Risiko yang dihasilkan juga lebih tinggi pasar dari pada risiko portofolio, sehingga kinerja yang dihasilkan lebih tinggi kinerja portofolio dari pada kinerja pasar. Hal ini disebabkan karena risiko yang digambarkan oleh standar deviasi yang dimiliki pasar sangat tinggi yaitu 0,037 yang memiliki selisih dengan return pasar 0,6\%, sedangkan return portofolio dengan risiko portofolio hanya selisih $0,1 \% .^{7}$

Dalam penelitian ini dilakukan dengan data terbaru pada kinerja harga saham yang terdaftar di JII yaitu data tahun 2020 .

\section{METODE PENELITIAN}

Adapun metode penelitian yang dipakai dalam penelitian ini yaitu penelitian deskriptif dengan pendekatan kuantitatif. Sumber data yang digunakan dalam penelitian ini adalah data sekunder yang diperoleh dari Historical Data yang diterbitkan www.yahoo.finance pada tahun 2020. Populasi yang digunakan pada penelitian ini adalah 30 perusahaan yang telah go public atau terdaftar di Jakarta Islamic Index untuk periode 2020. Dan teknik pengambilan sampel pada penelitian dilakukan dengan metode purposive sampling dengan mengambil 3 sampel

\footnotetext{
${ }^{6}$ Atik Budi Paryanti dan Sri Lestari. (2016). Analisis Penilaian Kinerja Portofolio Saham Dengan Menggunakan Metode Sharpe Measure Dan Treynor Measure Pada Saham-Saham Indeks Sektoral Yang Terdaftar Di Bursa Efek Indonesia (Bei) Periode 2008-2010. Jurnal CKI On SPOT, Vol. 9, No. 1.

${ }^{7}$ Mutmainah. (2017). Kinerja Portofolio Optimal Pada Saham Syariah. Jurnal Ekonomi Syariah Teori Dan Terapan Vol. 4 No. 12. (994-1008).
} 
perusahaan. Menurut (Sujarweni, 2015, p. 81) Sampel adalah bagian dari sejumlah karakteristik yang dimiliki oleh populasi yang digunakan untuk penelitian. Sujarweni (2015 p. 71) mengemukakan bahwa Desain Penelitian adalah pedoman atau prosedur serta teknik dalam perencanaan penelitian yang berguna sebagai panduan untuk membangun strategi yang menghasilkan model atau blue print penelitian.

\section{HASIL DAN PEMBAHASAN}

Penelitian ini dilakukan pada perusahaan yang terdaftar di Jakarta Islamic Indeks (JII) periode 2020 dengan data historis saham bulanan pada periode tersebut. Yang dijadikan objek perusahaan yaitu perusahaan Indah Kiat Pulp \& Paper Tbk (INKP) yang bergerak dalam bidang pembuatan kertas, pulpen dan kertas kemasan, perusahaan Vale Indonesia Tbk (INCO) yang bergerak dalam bidang pertambangan dan perusahaan Mitra Keluarga Karyasehat Tbk (MIKA) yang bergerak dalam bidang pelayanan kesehatan masyarakat/rumah sakit.

Data yang telah diperoleh diolah dengan cara-cara berikut ini yaitu :

1. Menghitung Tingkat Keuntungan Saham (Ri) Tiap Perusahaan

Tabel. 1 Keuntungan Saham (Ri) Tiap Perusahaan

\begin{tabular}{|r|r|r|r|r|r|}
\hline \multicolumn{1}{|c|}{ INKP } & \multicolumn{1}{c|}{$\mathbf{R i}$} & \multicolumn{1}{c|}{ INCO } & \multicolumn{1}{c|}{$\mathbf{R i}$} & \multicolumn{1}{c|}{ MIKA } & \multicolumn{1}{c|}{$\mathbf{R i}$} \\
\hline 7700 & & 3640 & & 2670 & \\
\hline 6750 & -0.12338 & 3160 & -0.13187 & 2600 & -0.02622 \\
\hline 5625 & -0.16667 & 2450 & -0.22468 & 2480 & -0.04615 \\
\hline 4010 & -0.28711 & 2160 & -0.11837 & 2150 & -0.13306 \\
\hline 5550 & 0.38404 & 2570 & 0.189815 & 1945 & -0.09535 \\
\hline 5250 & -0.05405 & 2780 & 0.081712 & 2370 & 0.218509 \\
\hline 5975 & 0.138095 & 2800 & 0.007194 & 2270 & -0.04219 \\
\hline 7800 & 0.305439 & 3420 & 0.221429 & 2400 & 0.057269 \\
\hline 9300 & 0.192308 & 3790 & 0.108187 & 2370 & -0.0125 \\
\hline 8975 & -0.03495 & 3560 & -0.06069 & 2450 & 0.033755 \\
\hline 9125 & 0.016713 & 4050 & 0.13764 & 2630 & 0.073469 \\
\hline
\end{tabular}


Institut Agama Islam Sunan Kalijogo Malang P-ISSN 2715-7725 E-ISSN 2721-9496

Volume 3 Nomor 2 Desember 2021

\begin{tabular}{|c|c|c|c|c|c|}
\hline 8675 & -0.04932 & 4610 & $0.1382^{\prime}$ & 2700 & 0.026616 \\
\hline 10425 & 0.201729 & 5100 & 0.1062 & 2730 & 0.011111 \\
\hline \multirow{4}{*}{$\begin{array}{l}\text { Return } \\
\text { (E(Ri)) }\end{array}$} & \multicolumn{2}{|c|}{ Kode Saham } & $\sigma_{\mathrm{I}}^{2}$ & $\sigma_{\text {I }}$ & \multirow{4}{*}{$\begin{array}{l}\text { 2. Mengh } \\
\text { Ekspekt }\end{array}$} \\
\hline & \multicolumn{2}{|c|}{ INKP } & 0.040639 & 0.201592 & \\
\hline & \multicolumn{2}{|c|}{ INCO } & 0.020107 & 0.141798 & \\
\hline & \multicolumn{2}{|c|}{ MIKA } & 0.008145 & 0.090248 & \\
\hline
\end{tabular}

Tabel. 2 Return Ekspektasian

\begin{tabular}{|c|c|}
\hline Kode Saham & $\mathbf{E}(\mathbf{R i})$ \\
\hline INKP & 0.04357122 \\
\hline INCO & 0.03791121 \\
\hline MIKA & 0.00543758 \\
\hline
\end{tabular}

Hasil Return Ekspektasian tertinggi dimiliki oleh saham INKP dengan nilai return ekspektasian sebesar 0.04357122 atau sebesar 4,36 \%. Sedangakan nilai return ekspektasian terendah dimiliki oleh saham MIKA dengan nilai sebesar 0.00543758 atau sebesar 5,87 \%.

3. Hitungan Varian Return dari Suatu Sekuritas $\left(\sigma_{I}^{2}\right)$ dan Standar Deviasi/Risiko $\left(\sigma_{I}\right)$

Tabel. 3 Varian Return dari Suatu Sekuritas $\left(\sigma_{I}^{2}\right)$ dan Standar Deviasi/Risiko $\left(\sigma_{I}\right)$

Dari tabel tersebut menunjukkan bahwa nilai varian tertinggi dimiliki oleh saham INKP dengan nilai sebesar 0.040639 dan terendah dimiliki oleh saham MIKA dengan nilai sebesar 0.008145. Begitupun dengan nilai standar deviasi tertinggi dan terendah masing-masing dimiliki oleh saham INKP dan INCO dengan nilai sebesar 0.201592 dan 0.141798.

Dikutip (Anggraini, Suharti, dan Nurhayati 2019:4) menyatakan Semakin besar standar deviasi maka semakin besar pula tingkat risiko saham pada masing-masing perusahaan.

4. Hitungan Tingkat Return Pasar (Rm), Return Ekspektasian Pasar E(Rm) Dan Risiko Pasar $(\sigma \mathrm{m} 2)$

Tabel. 4 Return Pasar (Rm), Return Ekspektasian Pasar E(Rm) Dan Risiko Pasar $(\sigma \mathrm{m} 2)$ 


\section{AL-IOTISHOD}

Jurnal Ehonomi Suariah

Institut Agama Islam Sunan Kalijogo Malang

P-ISSN 2715-7725 E-ISSN 2721-9496

Volume 3 Nomor 2 Desember 2021

\begin{tabular}{|c|r|r|}
\hline Bulan & \multicolumn{1}{|c|}{ IHSG } & \multicolumn{1}{c|}{ Ri } \\
\hline Desember 2019 & 6299.539 & \\
\hline January 2020 & 5940.048 & -0.0570663 \\
\hline February 2020 & 5452.704 & -0.0820437 \\
\hline Maret 2020 & 4538.93 & -0.1675818 \\
\hline April 2020 & 4716.403 & 0.03910011 \\
\hline Mei 2020 & 4753.612 & 0.00788927 \\
\hline Juni 2020 & 4905.392 & 0.03192946 \\
\hline Juli 2020 & 5149.627 & 0.04978906 \\
\hline Agustus 2020 & 5238.487 & 0.01725559 \\
\hline September 2020 & 4870.039 & -0.0703348 \\
\hline Oktober 2020 & 5128.225 & 0.05301519 \\
\hline November 2020 & 5612.415 & 0.09441667 \\
\hline Desember 2020 & 5979.073 & 0.06532984 \\
\hline E(Rm) & -0.00153 & \\
\hline om2 & 0.00585189 & \\
\hline
\end{tabular}

5. $\quad$ Menghitung Beta (ßi)

Tabel. 5 Hasil Perhitungan Beta Pada Saham

\begin{tabular}{|r|c|l|}
\hline \multicolumn{1}{|l|}{ No } & Kode Saham & Beta \\
\hline 1 & INKP & 1.848945 \\
\hline 2 & INCO & 1.541712 \\
\hline 3 & MIKA & 0.492852 \\
\hline
\end{tabular}

Dikutip dari (Anggraini dkk. 2019:5) menyatakan ketika harga saham emiten dengan beta kurang dari satu maka kenaikan atau penurunan lebih kecil dari IHSG. Harga saham emiten dengan beta diatas satu maka akan mengalami penurunan harga lebih besar dari pada IHSG. 
6. Menghitung Tingkat Pengembalian Bebas Risiko (Rf)

Hasil Perhitungan Tingkat Pengembalian Bebas Risiko yang diperoleh dalam penelitian ini yaitu sebesar 0.018978731 atau sebesar $1,90 \%$.

$$
\overline{\mathrm{Rf}}=\frac{\sum(\mathrm{Rf})}{\mathrm{n}}
$$

7. Menghitung Rasio antara Ekses Return dengan Beta (ERBi)

Tabel. 6 Hasil Perhitungan ERBi

\begin{tabular}{|r|c|c|}
\hline \multicolumn{1}{|c|}{ No } & Kode saham & ERBi \\
\hline 1 & INKP & 0.023565 \\
\hline 2 & INCO & 0.038106 \\
\hline 3 & MIKA & 0.164937 \\
\hline
\end{tabular}

Diketahui dari tabel 6 menunjukkan ERBi terbesar diperoleh saham MIKA dengan nilai sebesar 0.164937 ERBi terkecil diperoleh saham INKP dengan nilai sebesar 0.023565.

8. Menghitung Ai dan Bi

Tabel. 7 Hasil Perhitungan Ai dan Bi

\begin{tabular}{|c|c|c|}
\hline Kode saham & $\mathbf{A i}$ & $\mathbf{B i}$ \\
\hline INKP & 0.399623 & 16.95802 \\
\hline INCO & 0.638747 & 16.76242 \\
\hline MIKA & 0.443931 & 2.69151 \\
\hline
\end{tabular}

Hasil dari Ai terbesar dan terkecil dimiliki oleh saham INCO dan INKP dengan nilai masing-masing sebesar 0.638747 dan 0.399623. Sedangkan Bi terbesar dan terkecil masingmasing dimiliki oleh saham INKP dan INCO dengan nilai masing-masing sebesar 16.95802 dan 1,7821 
9. Menghitung Cut-Off Rate (Ci)

Tabel. 8 Hasil Perhitungan Cut Off Rate

\begin{tabular}{|c|c|}
\hline Kode Saham & Ci \\
\hline INKP & 0.047693 \\
\hline INCO & 0.067742 \\
\hline MIKA & 0.039204 \\
\hline
\end{tabular}

10. Pembentukan Portofolio Optimal

Tabel. 9 Hasil Komparasi Nilai ERBi dengan C*

\begin{tabular}{|c|c|c|c|l|}
\hline Kode Saham & ERBi & & C $^{*}$ & \multicolumn{1}{|c|}{ Keputusan } \\
\hline INKP & 0.023565 & $<$ & 0.067742 & Tidak Masuk ke dalam portofolio \\
\hline INCO & 0.038106 & $<$ & 0.067742 & Tidak Masuk ke dalam portofolio \\
\hline MIKA & 0.164937 & $>$ & 0.067742 & Masuk ke dalam portofolio \\
\hline
\end{tabular}

Dalam membentuk portofolio optimal dalam penelitian ini menggunakan Single Indeks Model. Portofolio yang optimum berdasarkan model indeks tunggal ditentukan dengan melihat nilai ERBi masing-masing saham yang memiliki nilai lebih besar dari C*. Penentuan nilai $C^{*}$ yang merupakan nilai Ci tertinggi, Ci tertinggi dimiliki oleh saham INCO dengan nilai sebesar 0.067742 . berdasarkan dari tabel di atas, dari saham yang diteliti hanya terdapat satu saham yang masuk ke dalam portofolio optimal berdasarkan model indeks tunggal.

11. Menghitung Wi dan Zi

Tabel. 10 Menghitung Wi dan Zi

\begin{tabular}{|c|c|c|c|}
\hline No & Kode saham & $\mathbf{Z i}$ & $\mathbf{W i}$ \\
\hline 1 & INKP & -18.434 & 1.672533 \\
\hline 2 & INCO & -24.7069 & 6.845499 \\
\hline 3 & MIKA & 32.1193 & 1.52241 \\
\hline
\end{tabular}




\section{Institut Agama Islam Sunan Kalijogo Malang}

P-ISSN 2715-7725 E-ISSN 2721-9496

Volume 3 Nomor 2 Desember 2021

Tabel di atas menunjukkan bahwa nilai Zi terbesar dimiliki oleh saham MIKA dengan nilai sebesar 32.1193 dan terkecil dimiliki oleh saham INCO dengan nilai sebesar -24.7069. Hasil Wi terbesar dan terkecil juga diperoleh saham INCO dan INKP dengan nilai masingmasing sebesar 6.845499 dan 1.52241.

Sesudah menghitung nilai Wi dan Zi langkah selanjutnya yaitu menetukan proporsi dana masing-masing saham.

Tabel. 11 Proporsi Dana Masing-Masing Saham

\begin{tabular}{|c|c|}
\hline Kode Saham & Proporsi Dana \\
\hline INKP & $40 \%$ \\
\hline INCO & $30 \%$ \\
\hline MIKA & $30 \%$ \\
\hline
\end{tabular}

Dari tabel di atas bahwa proporsi dana yang paling besar ada di saham PT. Indah Kiat Pulp \& Paper Tbk yakni sebesar 40\% dan proporsi dana pada PT Vale Indonesia Tbk sebesar 30\%, serta proporsi dana pada PT Mitra Keluarga Karyasehat Tbk sebesar 30\% juga, sehingga dapat dijumlahkan proporsi dana tersebut secara keselurahan yaitu 100\%.

12. Menghitung Tingkat Return Ekspektasian Portofolio E(Rp)

Tabel. 12 Hitungan Expected Return Portofolio

\begin{tabular}{|c|c|c|c|}
\hline $\mathbf{\sigma p}$ & $\mathbf{B p}$ & $\mathbf{E}(\mathbf{R m})$ & $\mathbf{E}(\mathbf{R p )}$ \\
\hline-0.05837 & -26.446 & -0.00153 & -0.01803 \\
\hline
\end{tabular}

Berdasarkan tabel di atas nilai return portofolio yang diperoleh bernilai negatif sebesar $(-0.0065)$ yang artinya tingkat keuntungan yang akan diperoleh dari portofolio tersebut adalah sebesar $-0,65 \%$.

\section{Mengitung Tingkat Risiko Portofolio ( $\sigma \mathrm{p})$}

Hasil Perhitungan Risiko Portofolio yang diperoleh yaitu 0.21801 dimana nilai tersebut lebih besar dibandingkan dengan return ekspektasian portofolio yang berarti portofolio memiliki tingkat risiko yang cukup tinggi. 
14. Kinerja Portofolio Dengan Metode Sharpe (Sp)

Tabel. 14 Hitungan Kinerja Portofolio dengan Metode Sharpe

\begin{tabular}{|c|c|c|c|}
\hline $\mathbf{E}(\mathbf{R p )}$ & $\mathbf{R f}$ & $\boldsymbol{\sigma p}$ & Indeks sharpe \\
\hline-0.01803 & 0.01898 & -0.05837 & 0.634059 \\
\hline
\end{tabular}

Dari di atas dapat dilihat bahwa indeks Sharpe yang diperoleh bernilai positif yakni sebesar 0.634059 .

Penelitian ini menunjukkan hasil dari ketiga saham yang diteliti hanya terdapat satu saham yang masuk ke dalam portofolio yakin PT Mitra Keluarga Karyasehat Tbk.

Pada penelitian ini juga menunjukkan bahwa portofolio yang telah dibentuk memiliki kinerja yang baik. Hal ini ditunjukkan dengan nilai dari Indeks Sharpe yang lebih besar yakni sebesar 0.634059 dibandingkan dengan nilai return ekspektasian pasar yang hanya sebesar (0.00153). Hasil penelitian ini sesuai dengan penelitian sebelumnya oleh (Rini, 2013, hlm. 7) penelitian menyatakan semakin besar nilai kinerja pada suatu portofolio, maka semakin baik pula kinerja portofolio tersebut. Penelitian tersebut membandingkan dua portofolio saham yang menunjukkan bahwa kinerja portofolio dengan model Sharpe pada semester I sebesar 0,471, sedangkan pada semester II kinerja portofolio sebesar 1,132. Hal ini menunjukkan bahwa pada portofolio terpilih di semester II memiliki kinerja yang baik daripada portofolio yang terpilih di semester I.

\section{PENUTUP}

\section{Simpulan}

Dari hasil penelitian di atas dapat disimpulkan bahwa saham PT Mitra Keluarga Karyasehat Tbk masuk kedalam portofolio dikarenakan memiliki nilai ERBi lebih besar dari C*, sedangkan Saham PT. Indah Kiat Pulp \& Paper Tbk dan PT Vale Indonesia Tbk tidak masuk kedalam portofolio dikarenakan memiliki nilai ERBi lebih kecil dari C*.

Berdasarkan perhitungan Metode Sharpe Index dapat disimpulkan bahwa portofolio yang telah dibentuk dari ketiga saham yang telah diteliti memiliki kinerja yang baik. Hal ini 
ditunjukkan dengan nilai dari Indeks Sharpe yang lebih besar yakni sebesar 0.634059 dibandingkan dengan nilai return ekspektasian pasar yang hanya sebesar (-0.00153). Hasil penelitian ini sesuai dengan penelitian sebelumnya oleh (Rini, 2013, hlm. 7) penelitian menyatakan semakin besar nilai kinerja pada suatu portofolio, maka semakin baik pula kinerja portofolio tersebut. Penelitian tersebut membandingkan dua portofolio saham yang menunjukkan bahwa kinerja portofolio dengan model Sharpe pada semester I sebesar 0,471, sedangkan pada semester II kinerja portofolio sebesar 1,132. Hal ini menunjukkan bahwa pada portofolio terpilih di semester II memiliki kinerja yang baik daripada portofolio yang terpilih di semester I.

\section{Saran}

Saran untuk peneliti selanjutnya diharapkan untuk dapat meneliti objek saham yang lebih banyak lagi dan dengan metode yang lebih baik lagi. Saran dalam penelitian ini yaitu untuk investor yang akan berinvestasi disaham, maka dapat menggunakan metode sharpe index sebagai salah satu alternatif dalam pemilihan kinerja portofolio dan menambah komposisi saham dalam portofolio sehingga menghasilkan saham yang optimal. 


\section{DAFTAR PUSTAKA}

Albaity, M., Ahmad, R., 2008, Performance Of Syariah And Composite Indices: Evidence From Bursa Malaysia, Asian Academy of Management Journal of Accounting and Finance.4(1), 23-43

Alwahidin. (2020). Kinerja Portofolio Saham Syariah dan Faktor yang Memengaruhi Kinerja Saham Syariah di Indonesia. Jurnal Studi Ekonomi Dan Bisnis Islam Volume 5, No.1. (17-41).

Anggraini, Dini, Titing Suharti, Dan Immas Nurhayati. 2019. “Analisis Metode Indeks Tunggal Dalam Pembentukan Portofolio Optimal." 10.

Asti Priyanti, Immas Nurhayati, Renea Shinta Aminda, dan Rasiman.(2021). Analisis Evaluasi Kinerja Portofolio Saham Dengan Metode Sharpe. Jurnal Manager Vol.4 No.2.hal. 174181.

Atik Budi Paryanti dan Sri Lestari. (2016). Analisis Penilaian Kinerja Portofolio Saham Dengan Menggunakan Metode Sharpe Measure Dan Treynor Measure Pada Saham-Saham Indeks Sektoral Yang Terdaftar Di Bursa Efek Indonesia (Bei) Periode 2008-2010. Jurnal CKI On SPOT, Vol. 9, No. 1.

Bank Indonesia Official Web Site-Bank Sentral Republik Indonesia. (n.d.). Retrieved September 9, 2020, from https://www.bi.go.id/id/Default.aspx

Elisa Vine Nurdhiana dan Dr.Norita,S.E.,M.Si.,Ak. (2017). Analisis Pembentukan Portofolio Optimal Menggunakan Capital Asset Pricing Model Serta Penilaian Kinerja Portofolio Berdasarkan Metode Shrape Ratio, Treynor Ratio, Dan Jensen. Jurnal e-Proceeding of Management : Vol.4, No.1.

Hartono. (2014). Teori dan Praktik Portofolio dengan Excel. Jakarta: Salemba Empat.

Herlianto, D. (2013). Manajemen Investasi Plus Jurus Mendeteksi Investasi Bodong (satu). Yogyakarta: Puataka Baru.

Kementerian Investasi/BKPM. Realisasi Investasi Triwulan I Tahun 2021 Rp. 219,7 Triliun, Kepala BKPM Optimis Target Investasi Tercapai. Diakses Pada April 2021. https://bit.ly/3CjyUda

Muthia Damayanti, Titing Suharti dan Diah Yudhawati. (2021). Penilaian Kinerja Portofolio Saham Syariah Dengan Metode Sharpe Index. Jurnal Manager Vol. 4, No. 1.

Mutmainah. (2017). Kinerja Portofolio Optimal Pada Saham Syariah. Jurnal Ekonomi Syariah Teori Dan Terapan Vol. 4 No. 12. (994-1008).

Paryanti, Atik Budi, dan Sri Lestari. (2016). Analisis Penilaian Kinerja Portofolio Saham Dengan Menggunakan Metode Sharpe Measure Dan Treynor Measure Pada Saham-Saham Indeks Sektoral Yang Terdaftar Di Bursa Efek Indonesia (Bei) Periode 2008-2010. Jurnal CKI On SPOT, Vol. 9, No. 1. (29-46). 
Institut Agama Islam Sunan Kalijogo Malang P-ISSN 2715-7725 E-ISSN 2721-9496 Volume 3 Nomor 2 Desember 2021

Permata, D., \& Suryawati, R. F. (2020). Analisis Portofolio Optimal Saham Syariah Jakarta Islamic Index (JII) Periode 2015-2017. Jurnal Manajemen Dan Organisasi, 11(1), 8-21. https://doi.org/10.29244/jmo.v11i1.30492

Rini, Sulistya, Siti Ragil Handayani, dkk. Evaluasi Kinerja Portofolio Dengan Menggunakan Model Sharpe (Studi Pada Perusahaan yang Listing Pada Indeks Lq 45 di BEI Periode 2012)

Sujarweni, W. V. (2015). Metodologi Penelitian Bisnis Dan Ekonomi (satu). Yogyakarta: PUSTAKABARUPRESS.

Syulvia, Sri Aeni, Siti Ragil Handayani, Dan Rustam Hidayat. 2015. “Evaluasi Kinerja Investasi Portofolio Dengan Menggunakan Model Treynor (Studi..Pada..Perusahaan Food \& Beverages Yang..Listing...Di Bei Periode 2013).” Jurnal Administrasi Bisnis (Jab) 23:10.

Tandelilin, E. (2010). Portofolio dan Investasi: Teori dan Aplikasi. Kanisius.

Yahoo Finance-Stock Market Live, Quotes, Business \& Finance News. (n.d.). Retrieved September 9, 2020, from https://finance.yahoo.com/

Zubir, Z. (2011). Manajemen Portofolio Penerapannya Dalam Investasi Saham. Jakarta: Salemba Empat. 